\title{
The Two-Level Game of Transnational Networks: The Case of the Access to Medicines Campaign
}

\author{
Jean-Frédéric Morin \\ Université libre de Bruxelles
}

\begin{abstract}
The rapid emergence of multi-stakeholder governance structures in world politics calls for an analysis of their power dynamics. Although multi-stakeholder structures are horizontal, they are not deprived of power struggles. By combining the advocacy network literature and the two-level game theory in an innovative manner, we attempt to understand the flow of influence between actors involved in a multi-stakeholder governance structure. Using the transnational debate on access to medicines as a factual background, we show how the structural characteristics of networks determine their influence on the outcome.
\end{abstract}

\section{Keywords}

Transnational advocacy networks; two-level game; global health; patent.

Recent years have witnessed an accrued interest in world politics for the development of multi-stakeholder governance. Fostering dialogue and building partnerships amongst advocacy groups, consumers, corporations, scientists, communities, and governments is increasingly presented as the appropriate process "to reach a sustainable development, balancing social and environmental, and economical objectives" (Cashore, 2002). As a result, multi-stakeholder initiatives are mushrooming in various issue-areas. Examples include the United Nations Global Compact, the Global Fund, Type 2 outcomes of the World Summit on Sustainable Development, the Forest Stewardship Council, the Kimberly Process on conflict diamonds, and the World Water Council.

Since Rosenau and Czempiel published Governance Without Government (1992), several scholars have praised these "synergies between networks of actors operating at multiple levels of international politics" and warn against "models based on an obsolete, exclusively state centric model of governance" (Haas, 2004). Others have refrained from passing normative judgments but have documented and explained the emergence of multi-stakeholder initiatives (Thérien and Pouliot, 2006). Few would question the fact that multistakeholder governance is an emerging empirical and normative reality of world politics.

Although what constitutes multi-stakeholder governance is still subject to debate, it is generally accepted that a classic structure can be recognized by the following four characteristics (Karkkainen, 2004). First, participation of all relevant stakeholders must be considered essential for the issue at stake and be included by the gatekeepers. Second, state and non-state actors must interact on a non-hierarchical basis. Third, decisions must typically be made by consensus rather than by vote or coercion. Finally, being defined by their issue rather than by their territorial jurisdiction, multi-stakeholder governance structures are most often transnational.

Critics highlight that engendering horizontal relations between relevant stakeholders and hoping for transnational consensus is overly optimistic, if not naïve or hypocritical (Steinberg, 2002; Kapoor, 2004). 
Defenders often respond that horizontal relations do not amount to equality (Risse, 2000:18-9). Though it is true that multi-stakeholder governance structures can level the playing field between state and non-state actors, it is increasingly acknowledged that such structures do not eliminate power struggles. But this line of analysis has not evolved beyond this recognition, leaving the nature and mechanics of the underlying power dynamics unclarified. As Carpenter notes, "measuring and understanding these [power] dynamics will lead to clearer insights" (2007:116).

This paper contributes to the growing body of literature on multi-stakeholder governance by providing a much-needed power analysis. While recognizing that state and non-state interactions are more horizontal than vertical in certain issue-areas, it pushes this general statement further by asserting that if certain conditions are met, power struggles can take place within a horizontal volume, thus providing a third dimension to the interplay among parties. This volume emerges by combining two existing but hitherto unrelated literatures, i.e. transnational advocacy networks and two-level game.

The next section proposes the conceptual framework connecting the literature on transnational advocacy networks with two-level game theory. The remainder of the paper illustrates that these two models can be theoretically and methodologically reconciled by using the example of multi-stakeholder governance for access to medicines in developing countries.

\section{CONCEPTUAlizing Network Two-LeVEl GAME}

This paper intends to bring light on the flow of influence among actors in a multi-stakeholder governance structure. In order to do so, our theoretical framework draws from the advocacy network literature for its particular insights on the social relations amongst sets of actors. Given the complexity of governance structures, the concept of network is of considerable aid to map out the state and non-state actors, as well as to understand their dynamics.

Keck and Sikkink's work on networks offers a valuable starting point to capture the transnational dimension of today's non-state actors. Importing the concept of network from organizational theory, they developed the notion of transnational advocacy network, which they define as a social organization associating "those relevant actors working internationally on an issue, who are bound together by shared values, a common discourse and who engage in a voluntary, reciprocal, and horizontal exchange of information and services" (1998:200). This conceptualization of networks mirrors the fundamental characteristics of global governance structures stakeholders are integrated in the analysis, decisions are consensus-based, networks show low formal hierarchy and spread beyond national boundaries.

More importantly for our purpose, Keck and Sikkink conceive that networks have a dual character. They function as agents acting on their own, influencing policymaking beyond the independent action of their components, while at the same time being structures following patterns of interaction among organizations and individuals (Kahler, 2009). Following an inter-constitutive approach, the nature of networks' agency derives from their structure, just as their structural nature is the creation of agents embedded within it.

Keck and Sikkink, however, limit their investigation to advocacy networks. They justify their approach by establishing a distinction between advocacy and business networks based on their different motives, the former being motivated by shared principled beliefs and values while the latter pursue instrumental goals. Drahos and Braithwaite (2003) and Sell and Prakash (2004), however, later challenged this assumption by arguing that normative frameworks and instrumental objectives inform both networks, although at different levels. They convincingly established that the transnational activities of NGOs and corporations are similar in that they organize coalitions, exchange information, use language to frame issues, and succeed in influencing public policy. The two networks should not therefore be treated differently. 
In light of the foregoing, one can go further and extend network analysis to governments. Graham Allison's study of the Cuban Missile Crisis has famously established that public policy is not the result of a unique and centralized agency but rather the internal debate of several departments with their own interests, priorities, and perceptions (Allison, 1971; Allison and Halperin, 1972). Internal debates are especially frequent on transnational issue-areas for which departments with domestic mandates rival those primarily concerned with foreign policy. These centrifugal forces within a government are nevertheless compensated by centripetal forces, such as a common bureaucratic culture and a shared commitment to advance the perceived interests of the country, holding the governmental network together.

However valuable the insights of the advocacy network literature may be, they are of limited salience to our analysis. Even though the concepts that underpin networks allow for the integration of power and influence to the multi-stakeholder governance literature, they insufficiently describe the interplay between several competing networks. Moreover, none of these analyses accounts for the complex nexus between networks' internal games and their external influence. As Hafner-Burnton, Kahler and Montgomery (2009) observed, research so far has focused on networks' effects on policymaking "rather than the effects of network structures on actors and outcomes within those networks."

In order to surpass this limitation, our theoretical framework also draws from a broad literature on the influence of domestic political considerations in international negotiations. In particular, Robert Putnam's two-level game theory (1988) provides a framework for understanding the interaction of domestic and international determinants of foreign policy. According to his metaphor, parties to an international negotiation are represented by a single chief negotiator who plays two games simultaneously. On one side, the negotiator seeks to achieve a common ground when negotiating with his foreign counterparts. On the other side, he strives to obtain domestic approval of the negotiated agreement. Consequently, in his attempt to satisfy both international and domestic pressures, the negotiator is caught in a strategic dilemma. Because moves at one level affect play at the other, policy choices are framed by constraints and opportunities at both levels.

The essence of the interplay between the two levels is captured by the key concept of 'win-set', defined as the set of all possible international agreements that would be acceptable at the domestic level (Putnam, 1988:437). According to Putnam, the size of the win-set depends on many variables, including ratification procedures, preferences of domestic actors and the strategic framing of the issue. Since the win-set delineates the array of policy choices at the disposal of each negotiator, an international agreement is possible only if domestic win-sets of all parties overlap. While a large domestic win-set provides negotiators with enhanced room for manoeuvre, the constraints imposed by a small domestic win-set can be used as an effective bargaining tool for international negotiations ("My constituents would not approve X, therefore we have to agree on Y"). Putnam predicts that the smaller a domestic win-set, the greater the chief negotiator's bargaining power on the international level. This advantage is met by the concomitant risk that negotiations will break down.

One of the fundamental weaknesses of Putnam's model is that it ignores the influence of the chief negotiators' preferences on the outcome of the negotiation. Andrew Moravcsik (1993) observed that negotiators' partial autonomy allows them to favour possible agreements in accordance with their own independently specified values. The set of agreements preferred by the chief-negotiator to the status quo is grasped by Moravcsik's concept of "acceptability-set". Further, Moravcsik imagined the possible relationships between the negotiator's acceptability-set and both domestic and foreign win-sets First, when the negotiator's acceptability-set encompasses the domestic one, he is a "negotiator-as-agent". When his acceptability-set lies partially outside the domestic win-set but closer to the foreign win-set, he is a "negotiator-as-dove". Finally, if his acceptability-set lies partially outside of the domestic win-set but further from the opposing win-set, he is a "negotiator-as-hawk".

Despite the great influence of Putnam's theory on competing domestic and international interests in foreign policy, and the value of Moravcsik's contribution, the two-level game metaphor articulated around chief 
negotiators is heavily state-centric and fails to give adequate attention to the reciprocal influence of domestic constituencies across different states. Moreover, the fact that the model disregards the transnational dimension of domestic/international interactions is rather problematic. Since the publication of Putnam's article in 1988, political scientists have well established that non-state actors, such as academics, nongovernmental organizations (NGOs) and corporations, have direct transnational activities that are not mediated by any governmental negotiator. Thus, the divide between international and domestic realms is increasingly artificial. As Keck and Sikkink correctly point out, Putnam's two-way street is too narrow and implies "a limited access to the international system that no longer holds true in many issue areas" (1998:4).

The theoretical model we propose seeks to analyse power dynamics in multi-stakeholder governance structures by combining two-level game theory and the transnational advocacy network literature. By doing so, we expect to overcome their respective pitfalls, namely and the state-centric aspects of the former and the incapacity to combine the agency and structural dimensions of network of the latter.

Although the alliance of a mechanical two-level game with a fluid transnational network model might seem artificial, the two bodies of literature naturally overlap on several subject matters. For instance, both Moravcsik and Keck and Sikkink observed that NGOs and corporations frequently bypass their chief negotiator and directly reach out to international allies to pressure their own governments (also known as the 'boomerang phenomenon'). Both literatures also deal with 'norm entrepreneurs', noticing their double game while spreading internationally endogenous norms developed in their own network/country, and importing exogenous norms to advocate for a minority position inside their own network/country (Boekle et al., 1999; Finnemore and Sikkink, 1998:893). Moreover, several authors noticed that the power of the two-level metaphor could be applied in the constructivist realm, whereby national norms could affect the international social system while international norms could play a role in internal dynamics (Müller, 2004:424; Boekle et al., 1999:8).

We propose a model under which the policy-making process involves several antagonistic networks operating similarly. We transpose Putnam's international and national interfaces to the intra- and internetworks and we replace the state chief negotiator by the network leader. On the intra-network level, these leaders recognize the strategic necessity to speak with a common voice and facilitate the attainment of a consensual standpoint to represent the group. At the inter-network level, most actors involved have insufficient resources to interact directly with all their counterparts. Therefore, their leaders debate to reach consensual agreement in a process similar to Putnam's international level game.

Through the lenses of our model, it appears that a network's internal games determine its win-set and leaders' bargaining power. The flow of influence within networks affects influence among networks. More particularly, where a network is constituted of a broad range of actors and has lively internal debate, it is likely to have narrow win-set, which gives the network's leader additional bargaining power. Nonetheless, lively internal debate also makes the network more vulnerable to outside pressure, especially to tactics aiming to influence actors at the margin of the network. Chances of failure to reach a consensual decision therefore escalate as win-sets narrow or move away from each other.

\section{THE CASE STUDY}

Combining network analysis with two-level game provides greater insights on power dynamics within multistakeholder governance. It allows for many networks to coexist and interact with each other and illustrates how networks act as both structures and agents. However, two conditions must be met for our model to apply to a specific case. First, there must be a sufficient number of stakeholders. Secondly, there must be a shared belief that the participation of all stakeholders, especially non-state actors, is essential. It should be noted that these two conditions are increasingly easy to satisfy since multi-stakeholder governance is, for better or worse, often presented as a panacea for transnational problems. Decision-makers increasingly 
consider that the participation of non-state actors provides legitimacy, reduces resistance and minimizes the blame for policy failures (Downs, 1967).

The concerted effort to improve access to patented medicine in developing countries provides a valuable illustration of international multi-stakeholder governance. Pressed by a coalition of transnational NGOs, WTO Members launched in November of 2001 a round of international negotiations to find an "expeditious solution" to the problem of access to medicines. Two years later, they adopted the so-called August $30^{\text {th }} 2003$ Decision, which relaxed the conditions under which a country with industrial capacity in the pharmaceutical sector can authorize a generic producer to manufacture and export pharmaceutical products, often through the intermediary of a NGO that buys and distributes them with the authorization of importing developing countries. Thus, non-states actors were the one supposed to use and implement the mechanism to reach the policy objectives fixed governments.

Shortly after the August 30 2003 Decision, Canada announced its intention to amend its Patent Act to authorize the export of generic drugs under patent protection. Canada's ambition was to fashion an unprecedented humanitarian mechanism that would be used by Canadian generic producers and praised by transnational NGOs without frightening foreign pharmaceutical patent-holders with investments in Canada. In order to find the appropriate balance between these competing objectives, the Canadian government saw the involvement and consensual support of non-state actors as necessary preconditions. From the Canadian government's viewpoint, it is "only through the concerted and sustained efforts of all relevant actors, developed and developing country governments, the NGO community, international trade bodies and the private sector, that real and meaningful progress can be made" (Government of Canada, 2007:5). As a result, the government conducted consultations described by a bureaucrat interviewed for this study as "the most intensive public consultation that has probably gone into recent legislative changes." NGOs, generic producers and patent holders from Canada and elsewhere were involved at all steps of the creation of the Bill. Although the Bill was adopted in Ottawa, the debate that led to its creation took place at the international level -involving transnational NGOs and firms, reaching all WTO members, and ultimately affecting developing countries.

In May 2004, the Governor General gave the Royal Assent to Bill C-9, known as the Jean Chrétien Pledge to Africa Act. The Bill was presented as "a joint effort between NGOs, drug companies and the Canadian government" (National Post, 16 July 2004). Ultimately, it received praise from around the world from rock star Bono, to UNICEF, the United States Trade Representative, and Pfizer.

In the following sections, Bill C-9 debate will serve as a factual background to illustrate our theoretical model and its methodological implications. Analyzing the interplay between intra- and inter-network debates is a four steps process. First, the competing networks must be mapped. Secondly, the leaders acting both at the intra and the inter levels must be identified. Thirdly, the win-set available to each leader must be estimated. Finally, the overlap of respective win-sets must be compared to the outcome of the debate.

\section{MAPPING THE NETWORKS}

Social network analysis offers a methodology to map relevant networks involved. As Scott observes, this methodology "embodies a particular theoretical orientation toward the structure of the social world" (1992:37). The structure of relations among actors and the location of individual actors in the network have important consequences for both the system and its individual units (Knoke and Kuklinski, 1982). From this point of view, actors and their relationships are viewed as interdependent, and therefore the unit of analysis is not the individuals themselves but the linkage among them. More specifically, the properties of the ties between actors - referred to as 'relational forms'- vary according to their intensity (strength or frequency of the interaction) and their degree of joint involvement (for instance, the reciprocal flow of information). 
So as to identify a network's structural properties, the researcher must specify boundaries for analysis by delineating a concrete population of social objects and the types of relationship connecting them (Knoke and Kuklinski, 1982:13). However, Mario Diani stresses that, "identifying the boundaries of the network is one of the most difficult problems" (2002:176). Social analysts can either apply a predefined conceptual framework on observed facts (the deductive approach) or use the subjective perception of networks' boundaries as determined by actors themselves (the inductive approach). Resorting to one or the other method should ideally give like results.

Although there is a growing literature on networks in the fields of both intellectual property (IP) and access to medicines, it was necessary to use a deductive approach as most analysts follow Keck and Sikkink and limit their study to advocacy networks (Mayne, 2002; Halbert, 2005; 't Hoen, 2002; Mowjee, 2003; Friedman and Mottiar, 2005). In an attempt to define and map networks' boundaries in Bill C-9 case, their nodes and ties were identified by analyzing three sources of information: (1) an exhaustive corpus of 73 press releases related to Bill C-9 (see Figure 1); (2) a compilation performed by Google of hyperlinks found on the websites of organizations mentioned in press releases (See Figure 2); (3) transcripts of 54 semi-structured interviews with key actors in the process (see Annex 1 for the list of interviewees). Indications of belonging to the same network include co-signing a press-release, mutual references to each other's websites, and organizations mentioned during interviews as allies or close collaborators.

Figure 1: Map of the NGO network using Netdraw and Ucinet. The strength of the ties is based on the number of joint press releases and the size of nodes represents the number of press releases.

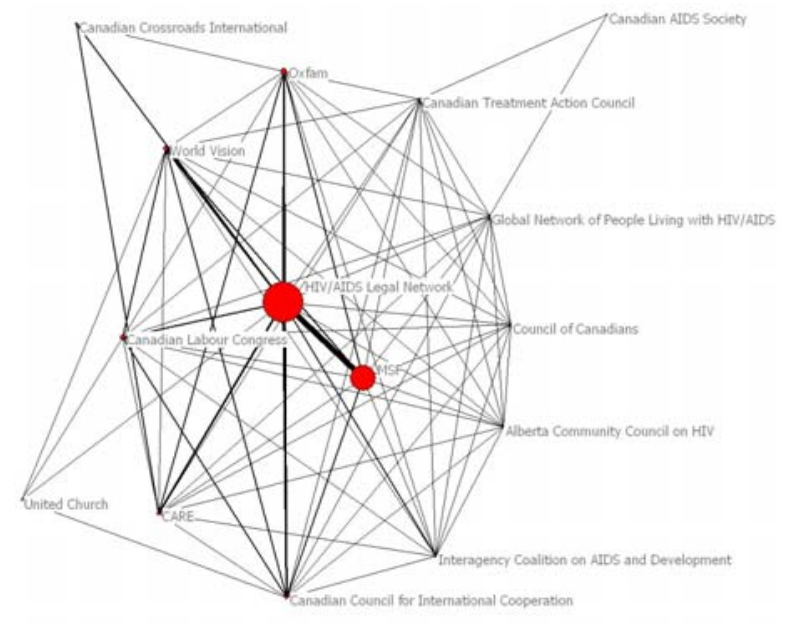

Figure 2: Map of the NGO network using Netdraw and Ucinet. The ties and nodes represent hyperlinks to other NGOs on Internet pages related to Bill C-9

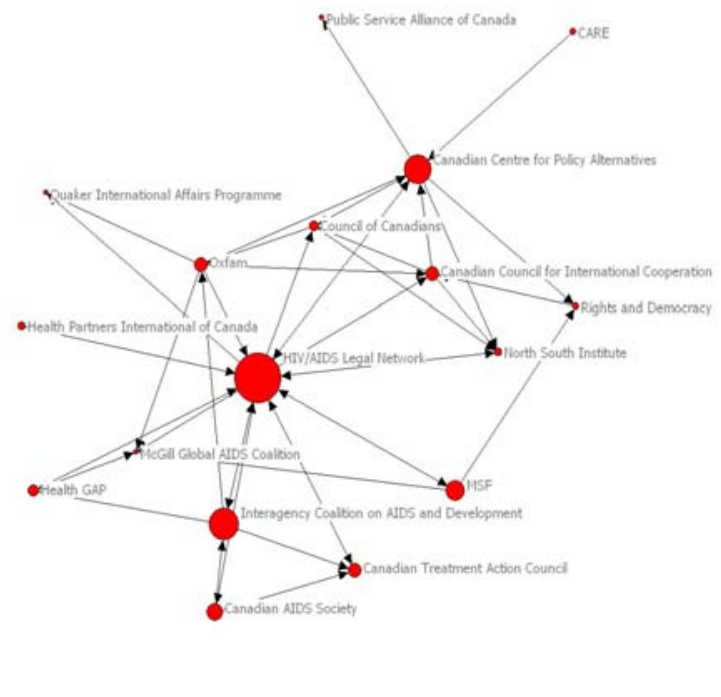

Our findings reveal the existence of four distinct networks. The first is the Canadian government. Most governments, with the notable exception of Switzerland's, do not have a central agency to coordinate all domestic and international policies pertaining to intellectual property. Within the Canadian government, the drafting of Bill C-9 involved five key departments, namely Health Canada, Industry Canada, Foreign Affairs Canada, International Trade Canada and the Canadian International Development Agency (CIDA), coordinated by the Privy Council Office. During the whole process, IP and global health specialists from these departments met regularly to exchange information, coordinate their objectives, and reach a common position. Most of them knew each other from working together on other files, and some have worked in various departments. Christopher Armstrong, for instance, was at CIDA when Bill C-9 was initially proposed, at Foreign Affairs when enacted, and back at CIDA when reviewed. 
Despite the fact that bureaucrats working within the same government did not conceive of themselves as a network, their interactions had all its attributes and characteristics. On the one hand, each agency had its interests, perspectives and organizational culture. Interviewees explained that very different sets of values were conflicting between Ministries, and that disagreement arose over most steps of the way. For a bureaucrat, this competition was a significant hurdle: "The more departments you have the longer it's going to take, the more complex it's going to be, and the more people you will have to bring on board." One the other hand, bureaucrats were committed to reaching common objectives. They "recognized that the five key departments would really have to work together." This coordinated effort is illustrated by the fact that most of the press releases on Bill C-9 included quotations from the five key ministers and contact information from all five departments.

While the government network is national-based, IP business networks have a larger reach. Members of this network are united by the instrumental objectives of increasing worldwide protection for pharmaceutical inventions and share the normative belief that high standards in patent protection increases social wealth and improve global health. They are institutionally organized in various business associations, including the International Federation of Pharmaceutical Manufacturers and Association (IFPMA), and often refer to their collective identity as the "innovative pharmaceutical community." "

Several members of this transnational business network took an active part in the Canadian debate on the implementation of the August $30^{\text {th }} 2003$ WTO decision. Most companies expressed reservations because of the potential erosion of IP protection in emerging markets such as China, Brazil and Argentina. As Canada was the first mover among WTO members, its legislation had the potential to serve as a model for other countries. It was therefore crucial for them to frame the debate and hold sway on policy-making. For example, during the 2007 review of the legislation, eleven foreign-owned pharmaceutical companies and five of their industry associations, including the European R\&D-based Pharmaceutical Industry and the Irish Pharmaceutical Healthcare Association, sent individual submissions to the Canadian government. The submissions revealed a coordinated discursive strategy by expressing the same ideas and frequently using the exact same language.

In addition to the business network, a transnational NGO network advocating for access to medicines in developing countries was very active during the Bill C-9 process, especially through agenda-setting, publicmobilizing and direct advising. It included faith-based groups with large constituencies (such as United Church), think tanks with research expertise (such as the North South Institute), labour unions with extensive administrative resources (such as the Canadian Labour Council), development advocates with strong communication skills (such as Oxfam) and humanitarian organizations with testimonies from the field (such as Médecins Sans Frontières).

Those NGOs were brought together "by the same views, the same values, and the same ideology," and as an interviewee from the NGO network said, each of them "brought something to the table". He adds, "we're all coming from the same basic perspective which is that poor people should have access to medicine". Therefore, as another recalls, when Canada announced its desire to implement the WTO decision: "We knew very quickly, inherently really, because of the way NGOs work, that we have to be together." The frequent use of words like "we", "our allies", or "our colleagues", reveals a strong sense of collective identity between NGOs.

During their campaign, the NGO network operated through a pre-existing coalition called the Global Treatment Access Group (GTAG). GTAG became the focal point for regular exchange of information and the development of common strategies, mostly through emails and conference calls. Given that GTAG did not have a formal list of members and was essentially based on personal connections, it should be conceived of as a network of individuals rather than a network of organizations. As an interviewee said, "when there

\footnotetext{
${ }^{1}$ Mr. Russel Williams (President, Canada's Research-Based Pharmaceutical Companies (Rx\&D)) hansard, committee,
} 23 April 2007. 
are new people coming into that network of contact, it is often through another contact." Some individuals even travelled within the network, like Marie-Hélène Bonin who moved from Médecins Sans Frontières (MSF) to the Canadian Labour Congress. Several interviewees mentioned their friendship with other GTAG members relating the "familiarity, trust and respect that have built up over years." As an interviewee summarized, "in NGOs, it's always like that, it's all about individuals."

Our findings revealed the existence of a fourth network involved in the debate. Indeed, the business network must be divided between the brand name and the generic networks. This stood out especially as an interviewee working for one group qualified the other as their "arch enemy," explaining that "on virtually every issue there is, our position would be the opposite of theirs."

Sell and Prakash (2004:149) insist that the generic industry should be included in the NGO network because both share an interest in relaxing patent standards. They argue, for example, that Cipla, an Indian generic manufacturer, was a "key member of the Access Campaign," notably because the very special rates they offered to MSF served as a critique of the prohibitively high prices of patented pharmaceutical. However, analysis of press releases, website and interviews reveal that NGOs and the generic industry belong to two different networks. All the members of GTAG interviewed were very clear on the fact that generic companies were not considered as one of their own. They were deliberately excluded from the collective "we". They were considered, just like bureaucrats and brand name representatives, as "the guys in suits." Several NGO representatives explained that not only did the generic industry have different end objectives, but they could not be trusted more than the brand name industry as both are driven by profit. "We try to keep our distance in this," one explained, "we didn't want to be seen to be pro-generics." For example, when MSF negotiated a contract with the generic producer Apotex in order to use the Canadian mechanism, their communication specifically avoided depicting their relationship as a "partnership", but only as a "cooperation" so to reassure that they were not members of the same network.

The strategic decisions of generic producers to keep a low profile during WTO negotiations partially explains why this fourth network has been overlooked by previous research efforts. Interviewees working with the generic industry acknowledged that they preferred investing their political capital in other policy issues as they did not foresee enough business opportunities. Nevertheless, members of the Canadian Generic Pharmaceutical Association (CGPA) started to play a more active role when the debate moved from Geneva to Ottawa. They started developing their own discourse focusing on price as their competitive advantage. They also defined their policy objectives to protect themselves from legal disputes initiated by brand name companies. Moreover, third parties recognized the existence of the generic network as a cohesive, legitimate and organized group of actors. As unpublished governmental documents show, the generic industry was systematically distinguished from the other stakeholders.

Relying on press releases, websites and interviews, four networks were identified. Nonetheless, this should not suggest that every actor was an active member of one of these networks. Some actors gravitated around the existing networks and made independent contributions, like political parties in the opposition (such as the New Democratic Party which played an active role), academics (such as Frederick Abbott, Jillian Cohen, Amir Attaran, James Orbinsky and Joel Lexchin), prominent public figures (Stephen Lewis and Bono) and intergovernmental organizations (the World Health Organization and UNICEF). Conversely, some groups deliberately decided to remain at the margins, such as the Quaker United Nations Office and Health Partners International Canada.

\section{IDENTIFYING NETWORK LEADERS}

Although a network's structure is a key variable determining its success, structure alone "cannot deliberate, imagine, strategize or engage in decision-making" (Morris and Staggenborg, 2004:187). Network leaders are the necessary interface between the two games. As one interviewee said, "if you try to isolate the actors, you 
see there are few actors that have been involved in each coalition; they are sort of the nucleus and they are organizing the coalition around it."

Ascendance among peers does not derive solely from intrinsic resources attached to particular individuals, such as charisma or financial means. Rather, power flows stem from the leaders' positions in network environments (Ganz, 2003), and consequently, networks tend to coalesce around a few active leaders located in core positions and surrounded by layers of peripheral actors. A leader's strategic position in the network provides him with two important advantages over other actors, namely easy access to diverse and salient knowledge, as well as a channel to diffuse ideas and information to their peers. Leaders therefore function as translators: within the network, they mobilize and inspire their members, and outside the network, they distil and articulate the substance of internal exchanges (Gusfield, 1966). For this reason, they are often nominated as spokespersons or selected by the media to act as representatives. In a situation like that of Bill C-9's drafting and implementation, leaders are responsible for altering a pre-existing institutional framework in order to accommodate the network's preferences, while shaping these preferences in accordance with the institutionally embedded framework (Morris and Staggenborg, 2004:186). They are, as Putnam's chief negotiator, at the interface of two games.

In the debate over Bill C-9, leadership was often assumed by umbrella organizations. Several interviewees from the brand name network explained that business associations such as IFPMA and Rx\&D have much greater ability to express their opinion to policymakers and the media than any specific companies. As one explained, a business association "is not a brand, [it] doesn't sell medicines, so their image doesn't matter as much." Companies prefer not to take the stand on public policy issues; they would rather delegate this role to associations, which are less sensitive to public perception and reputation. "It's our role to be out there as advocates; and companies prefer having us than having that role," confirmed an interviewee from a business association.

When the Canadian government announced its intention to implement the WTO Decision, the first reaction came for the international industry association. Harvey Bale, the Director of Geneva-based IFMPA, warned the Canadian government that its initiative would be "a negative black eye" that will "very well affect the investment climate" (Globe and Mail, 27 Sept. 2003, A1). But less than a week later, the Canadian $\mathrm{Rx \& D}$, representing the very same companies, clearly took a leadership role and abandoned IFPMA's confrontational approach. As a lobbyist working outside of Canada explained, "Rx\&D were talking to [the Canadian] government because they had [a] relationship compared to other [foreign] companies" and industry associations. Despite the fact the international, American and European industry associations took the Canadian Bill "very seriously" and were regularly consulted for their key expertise acquired at the WTO, they delegated the leadership role for the Bill C-9 debate to Ottawa-based Rx\&D.

In the generic network, the leadership role was assumed by CGPA. During the drafting and amendment processes, CGPA issued six press releases on Bill C-9, sent detailed submission to parliamentary committee, and it was even invited to read and comment upon undisclosed drafts of the Bill. Apotex, as the largest Canadian-owned pharmaceutical company, was also a crucial player in this network. It had more products to offer to developing countries, and therefore more interest in developing new ones than any other generic manufacturer. That is why Apotex regularly met with NGOs and policymakers to discuss the drafting and implementation of the Bill. Moreover, the company upheld a constant interest and expressed a nonequivocal commitment to the issue. As a result, Apotex became the first company worldwide to have used the WTO mechanism in 2007. One could even doubt that the CGPA would have played such an active role without the involvement of this key member.

Within the government network, interviewees designated Industry Canada as the predominant player, although each of the five departments cited above made some contributions and even took the lead on specific issues. Industry Canada's leadership was visible as it bore precedence in parliamentary hearings being first to speak- and in interdepartmental press releases where their perspectives and contact 
information would show first. Industry Canada's leadership attributes derived from several factors. First and foremost, the Patent Act is under its administration. Its responsibilities and expertise on IP law, which it shared with Health Canada, gave it "a certain credibility." Its leadership also came from Allan Rock, its Minister, who according to an insider, "made it a personal issue for him and led the charge in Cabinet, and he sort of was able to overcome any obstacles or inertia that might have otherwise held up the policy development process."

The Privy Council Office (PCO) also played an important but secondary role within the government network. It was responsible for briefing the Prime Minister, supporting the Cabinet process and coordinating the different departments. It was especially concerned about the unity of government's public views and interests, either real or perceived. In short, the PCO made sure that the government ultimately spoke with one voice. If Industry Canada was leading the substance of negotiations, the PCO was leading the interdepartmental process.

In the case of the NGO network, the structure was substantially different. As one interviewee said: "there was not a functioning structure, an office, or a paid coordinator" Existing umbrella organizations such as the Canadian Council for International Cooperation or the Inter-Agency Coalition on AIDS and Development were involved in the debate but were not considered official leaders. Moreover, it was decided not to transform the GTAG in a formalized umbrella organization with a single budget, membership, spokespersons and branding. Not only was there insufficient time and resources to create such an organization, but as several interviewees also pointed out, the flexibility of an informal coalition and the weight of some existing NGOs' brands were key assets that they wanted to preserve.

There were three layers of actor involvement in the NGO network that can be illustrated by three concentric circles. At the periphery were organizations such as World Vision and the North-South Institute. Most of them readily recognized their minor role in the discussions: "we were involved sporadically but not all the time." The second layer include actors who were frequently mentioned in our interviews, such as Oxfam, the Canadian Labour Congress, the Canadian Council for International Cooperation, and the Inter-Agency Coalition on Aids and Development. Finally, at the heart of the network, the first circle was constituted by Médecins Sans Frontières and the HIV/AIDS Legal Network, almost unanimously recognized by interviewees as the "elite group". They published by far the highest number of press releases, articles and open letters and were the most quoted in the media ${ }^{2}$. They were "the core where everything came together."

The leadership of this nucleus derives from four attributes. First, they possessed legal and medical expertise that proved to be useful. For instance, the HIV/AIDS Legal Network provided the necessary legal knowledge to argue that a closed list of medicines was not a requirement under the TRIPS Agreement. As for MSF, they had the medical expertise to determine which important drugs were missing in the governmental list. Secondly, both organizations had instrumental contacts in Canada as well as in developing countries. Because the Canadian branch of MSF was part of the broader MSF network, they had lobbyists following the debate at the WTO as well as persons that could provide testimonies from the field. As of the HIV/AIDS Legal Network, it is a genuine Canadian organization with close connections to two key South-African NGOs (the AIDS Law Project and the Treatment Action Campaign) that participated in the debate and sent their own submissions to the Canadian government. Thirdly, both MSF and the HIV/AIDS Legal Network had the capacity and the willingness to devote resources, especially human resources, in the campaign and potentially at the expense of other policy issues. Lastly, the individuals working in these two organizations clearly demonstrated leadership. Richard Elliot, Marie-Hélène Bonin and Rachel Kiddell-Monroe were described by their peers as passionate and dedicated individuals.

\footnotetext{
${ }^{2}$ From the 87 newspaper articles published on the Bill-C9 from 31 August 2003 to 25 November 2006, the most often quoted NGO representative is Richard Elliott from the HIV/AIDS Legal Network and the most often quoted NGO (with various representatives) is MSF. Also, Richard Elliott and Rachel Kiddell-Monroe (from MSF) are the NGO representative most often mentioned in newspaper articles without being quoted.
} 
Leaders of the four networks had a double mandate. Internally, their role was to mobilize and consult with their members in order to speak with a common voice. They focused essentially on sharing information, galvanizing their network, and as one said, sold their ideas to their partners. Externally, they had to interact with one another, either directly, during private meetings, or indirectly, through the media. The key concept of win-sets is found at the intersection between these two levels.

\section{ESTIMATING THE WIN-SET SIZE}

Many variables can be expected to have direct effect on leaders' bargaining power. Drawing from Putnam's discussion on the variables of a win-sets and Moravcsik's concept of acceptability set, it appears that at least five factors can enhance bargaining power by reducing the win-set size: (1) the network's tolerance of the status quo; (2) heterogeneity of interests; (3) the network's tolerance of dissension; (4) the leader's autonomy; and (5) the leader's strategic preferences.

The first variable that contributes to reduce the win-set size is the network's tolerance of the status quo. If a 'no-agreement' outcome bears little or no cost for a network, the latter is likely to be less compromising or more easily opposed to the agreement. On the other hand, if the status quo persists at great cost or represents a worsening situation, the network will likely show general support for the legislation. Thus, as a general rule, a lower cost to maintaining the status quo will engender a smaller win-set.

Since maintaining the status quo was not an appealing outcome for the brand name network, they showed consistent support for the proposed Bill. After the bad press they received at the 1999 South African trial, the industry rallied in support of Bill C-9 and wanted to be seen as supportive. The brand name companies repeatedly said that they "support[ed] the laudable goals of the Doha Decision," and at most expressed a mere "disappointment" for a specific measure. The government also showed general support for the legislation since the decision to implement the WTO Decision had been announced to electors just before the elections in the spring of 2004. Although scepticism about the feasibility of the Bill was high within the governmental network, pressure from the executive thwarted all resistance. As an interviewee said, "a lot of people in the Canadian government, senior level, would not have done it, but once you have the Prime Minister saying, "I want to get this done", then the whole dynamic changes and it gets done." As the political cost of no-agreement was perceived as being high, they were ready to compromise to achieve consensus.

In contrast, NGOs were neither committed nor pressured to support the agreement. In fact, they had an interest in drawing out the discussion. Should the debate come to a standstill, some NGOs could successfully have demonstrated the failure of the mechanism and, as an interviewee said, show "that it's all a waste of time and we should be looking for completely different ways of doing this." Generic companies had an interest in the status quo as well. As a key player in the generic industry commented, "there's no way that this bill is ever going to be able to be used." Given this skepticism, their commitment toward reaching an agreement was low. Besides, they were afraid that any measure would thrust expectations upon them, since any adopted mechanism would require managing expectation that generic companies could not alone save developing countries.

The heterogeneity of interests is the second variable affecting the win-set. The presence of heterogeneous interests among members reduces the scope of possible agreements that are available. In a homogenous group, the network leader can seek to obtain maximum concessions from his opponents without being afraid that his members will complain of too many gains. However, in a heterogeneous group, division creates possibilities of defection if, in the eyes of the members, the agreement realizes too little or too much. Internal coalitions, issue-linkages and trade-offs that are typical of heterogeneous group complicate the constitution of a joint platform, increase the risk of factionalism, reduce the number of potentially 'winning' agreements, and consequently impact the win-set size. 
The network showing the highest level of homogeneity was the brand name industry. When the companies sent their own submissions to the government, they typically specified in the introduction that they "fully support the submission by our industry association." Their interests were fairly homogenous, although some companies, like Pfizer, had more stringent positions on the protection of their patent rights than others, such as Merck. Their debate was more about the appropriate strategy than about their shared interests. As for the generic companies, they expressed no opposition to the Bill. Although Apotex was showing an ongoing interest in the legislation, most other companies kept a low profile. They did not strongly support nor oppose the Bill. With respect to internal coalitions, the brand name industry and the generic companies networks could not be said to have really exploited issue linkages. While the pharmaceutical and generic industries tried to deviate the debate toward other issues (the former emphasizing on health infrastructure and corruption in developing countries and the latter hoping to secure government buying as part of development assistance), these linkages were merely strategies aimed at minimizing cost or maximizing benefits.

A completely different situation took place within the NGO and government networks, which was subject to considerable internal debate. In the former, markedly different opinions were expressed with respect to objectives and resources. Not only did the NGO network group comprise a wide range of organizations with heterogeneous interests, but it was also divided between radicals and reformists. As one interviewee explained, "people have different bottom lines on how flexible they are, what they are willing to accept." Locally based and transnational organizations, religious groups and AIDS activists, pragmatic doctors and dogmatic protestors had to agree on a common platform combining development and health issues. One contentious issue within the NGO network was whether or not generics should be allowed to profit from this mechanism. As one interviewee said, "the free stuff is not sustainable." But other NGOs were rather focused on the humanitarian dimension and were "not worried about whether it's profitable or not." Each internal coalition between NGOs was thus setting new expectations towards the Bill while also reducing its chances of success.

At the governmental level, the departments' different interests, perspectives and organizational cultures frustrated internal cooperation. Concerns ranged from drug safety and efficacy to international standing of the country. The five departments nevertheless agreed on a triple objective behind the adoption of the Bill, namely the improvement of access to medicines in developing countries while respecting international trade rules and maintaining the integrity of the domestic patent system. Although those objectives are not necessarily in conflict, their overlap is thin and precarious.

The third factor influencing the win-set size is tolerance to dissension. Contrary to the heterogeneity within the network, this variable measures the cost rather than the risk of factionalism. Thus, among networks striving with internal debate, the tolerance to audible divergent opinion can vary. The lower the tolerance to dissenting voices, the higher the necessity for the leader to take into account the disparate interests of members. This added responsibility reduces the win-set.

For NGOs, generic manufacturers and the brand name industry, the cost of dissension is high but tolerable. Within the NGO network, for example, intolerance to dissenting voices was manifest after the Canadian Access to Treatment Coalition left the network. The network reacted strongly to this event and, as one interviewee recalls, "that was one of the tough moments, and we sort of lost a partner in the process at that time." The same state of shock happened twice with MSF. In 2004, MSF refused to sign a press release considered too compromising and instead issued its own entitled: "How Canada Failed the International Community"(29 April 2004). A year later, MSF also refused to support an NGO platform that sought to address issues other than access to medicines. These were painful but not insurmountable moments.

The government network is, by nature, much more intolerant to any leakage of dissenting voices. Although competition between departments is inevitable, the government wanted to be seen by the electorate as a united team. Dissenting voices within an informal NGO network or industry association, if noticed by third party, rarely challenge the credibility of the entire network. The government, however, has a greater stake in 
being perceived as working toward a coherent goal. The five departments thus repeatedly expressed their position with a single voice. As one interviewee maintains, "I think probably no department or no Minister wanted to be seen as the one who was blocking this [Bill] from happening [...] nobody was interested in having that kind of media coverage."

The fourth variable to consider is the leader's autonomy vis-à-vis the network. As a general rule, the more autonomy a leader enjoys with respect to decision-making, the larger his win-set. A leader ultimately perceived as immune from internal pressures loses considerable bargaining power because he cannot invoke lack of internal support as a constraint. Conversely, a leader with little autonomy will see his win-set reduced for he is bound to the position of his members.

Leaders in the generic and brand name industry, respectively Rx\&D and CGPA, depend on their members, and have little autonomy to act contrary to their interests. As trade associations, they do not have the material and political capacity to ignore the mandate given to them by their contributors. Far from being authoritative, they could be described as 'serving leaders'.

Within the governmental network, Industry Canada had more autonomy. The Patent Act is under its authority and its expertise is incontestable. That being said, it could not have imposed the decision unilaterally because of its lack of formal authority on other ministries. Industry Canada was simply first among its peers.

In the NGO network, members refused to adopt a sole leader to speak on their behalf. As one interviewee explains, electing a spokesperson for all NGOs would likely interfere with some strong and influential members who "would not allow anyone to speak on their behalf." Since the network relinquished to work under an umbrella organization, its leaders enjoyed great autonomy and generally spoke on their own behalf.

The fifth and last variable is the leader's strategic preferences. Moravcsik's amendment to Putnam makes clear that a chief negotiator is likely to favour agreements that match his acceptability-set. For instance, the leader can deliberately adopt a non-cooperative approach in order to force his counterparts on his ground and act, in Moravcsik's terms, as a leader-as-hawk. Alternatively, if the leader adopts a cooperative approach, he is a leader-as-dove.

Although brand name industry associations has often played the leader-as-hawk in public policy debates, in this case, $R x \& D$ was a leader-as-dove. Soon after the Canadian government's announcement that it would implement the WTO decision, the transnational pharmaceutical companies abandoned their previous confrontational approach. They changed for a more cooperative one, as shown in their press releases using terms such as partnership, cooperation, coordination, jointly, together, agree, and shared.

At the government level, Industry Canada was primarily concerned with maintaining the equilibrium of the Patent Act. Other objectives, such as insuring a better access to medicines in developing countries or implementing safety measure for the imported drugs, were never endorsed by the leading agency. In light of this, Industry Canada qualifies as a leader-as-hawk since its acceptability-set lies partly outside of the domestic win-set, and even further from the opposing win-set.

The NGO network had MSF, often pictured as cut-and-dried, less compromising, and more arrogant, as their leader-as-hawk. Several NGOs considered that having MSF was a key attractive force and helped the overall campaign. Two interviewees underlined the French root of MSF to explain why they were less consensus-orientated. 
Table 1 - Variables contributing to the reduction of the win-set size in the Bill C-9 debate

\begin{tabular}{|c|c|c|c|}
\hline & \multicolumn{3}{|c|}{ Larger win-set $\longleftrightarrow$ Smaller win-set } \\
\hline & Low (1) & Medium (2) & High (3) \\
\hline Tolerance to status quo & $\begin{array}{l}\text { Band name } \\
\text { Government }\end{array}$ & Generics & $\mathrm{NGO}$ \\
\hline Heterogeneity of interests & Band name & Generics & $\begin{array}{c}\text { NGO } \\
\text { Government }\end{array}$ \\
\hline Intolerance to dissension & & $\begin{array}{c}\text { Band name } \\
\text { Generics, NGO }\end{array}$ & Government \\
\hline Leaders' dependence & $\mathrm{NGO}$ & Government & $\begin{array}{c}\text { Band name } \\
\text { Generics }\end{array}$ \\
\hline Leader's preferences & Band name & $\begin{array}{c}\text { Generics } \\
\text { Government }\end{array}$ & NGO \\
\hline Total: & NGO: $12 ; \quad G$ & ht: 11 ; Generic: & and name: 8 \\
\hline
\end{tabular}

The five aforementioned variables contribute to the complex interplay of power forces in multi-stakeholders governance, as the Bill C-9 debate makes explicit. It appears from our analysis that the NGO network, closely followed by the generics and the government, had accumulated the most variables that reduce win-set size (see Table 1 below). According to our model, their networks would have the smaller winsets and potentially greater power to influence outcomes. As the next section will detail, this hypothesis has proven true in the case of Bill C-9.

\section{COMPARING WiN-SETS OVERLAP WITH OUTCOME}

Ultimately, the four networks behaved in accordance with the revisited version of the two-level game theory, and therefore, Putnam's predictions. First, his prediction that parties with smaller win-sets have higher bargaining power was confirmed with the NGO and government networks. The legislator adopted many of the proposals submitted by the NGO and the generic networks, like the removal of the "right of first refusal" clause, the expanded list of beneficiary countries, the revision of the categories of eligible purchasers and the inclusion of additional products in the list of eligible drugs for export. The government was also able to include some of its own ideas, such as the pricing scale, that was not anticipated by any stakeholder. As interviewees from all sides admitted, NGOs, generic producers and bureaucrats had a "significant impact on the legislation."

Secondly, Putnam anticipated that the possibility to reach an agreement was dependent upon the overlap of parties' win-sets. Thus, the opportunity to reach consensus on Bill C-9 has been greatly enhanced by the brand name network's large win-set. Faced with a public relations disaster, their objective became the mitigation of losses. They realized that their material interests could be spared and their reputation improved if they cooperated and supported the suggested mechanism. Thus as they readily admit, they decided to "conceded on some demands."

Not only did the parties behave in accordance with the two-level game but they also seem to have consciously maximized it in two ways. Indeed, relevant actors were familiar with the two-level game at play. At the intra-network level, most networks recognized the strategic necessity to speak with a common voice. Aware that only a strong and cohesive network would be successful, they strived to find a consensual standpoint to represent the group. As one interviewee from the NGO network explained: "If you have too many messages, then they divide to conquer. So it is very important to show that you have some cohesion, that there is one message." And a policymaker confirmed the effectiveness of the latter strategy: "Having all these NGO's involved with this and all focusing in the same direction, I mean, government they listen."

Parties also planned strategies at the inter-network level. When a network is subject to lively internal debate, it is also more vulnerable to tactics intended to influence marginal actors. As Keck and Sikkink explain, 
"undermining a dense network rather requires destructuring it -that is, eroding the relations of trust or mutual dependence that exist among networked actors" (1998:207). Thus, network leaders often strategically targeted a player at the margin of another network in order to establish partnerships, share information, create alliance or weaken a rival network.

The NGO network has been especially targeted by this tactic since their internal dissension, exhibiting some degree of weakness, was perceivable from the outside. Health Partners International of Canada, for example, received free medicines and vaccines from brand name companies, and at the end, supported the brand name idea of a tax credit for drug donations. Similarly, the bureaucrats from the five department find it useful to meet with a small group of NGO representatives, isolated from their coalition, because "they didn't have a lot of time for turnaround, so they were actually very helpful tender comments." That being said, the same tactic was used against the government network. Some bureaucrats had privileged meetings with stakeholders in the absence of their colleagues and thus obtained from these meetings information necessary to support their position in the internal governmental debate. As a result, the industry representatives considered that "we had some people in the (administration) working in our direction" and some NGOs recognized that they were "playing one department against another." Finally, both NGO and government representatives tried to bypass industry associations, described as "not good interlocutors" because they repeatedly state pre-determined positions. Rather, they sought to interact directly with their "forwardlooking CEOs," seen as more receptive but also more difficult to reach.

\section{CONCLUDING REMARKS}

Viewed through these lenses, the Bill C-9 case illustrates a revised version of the two-level game theory, shows how structural features of networks can have significant influence on the outcome, and confirms the assumption that the strength of networks as agent spring from their force as a structure. A network involving a broad range of actors with lively internal debate may lead to a narrow win-set, and, if well communicated, can give additional bargaining power because its counterparts know that they cannot support a outcome outside of this framework if they want member support. At the same time, until a win-set is defined, lively internal debate makes networks vulnerable to external pressure and tactics. As Keck and Sikkink correctly assert, "the network-as-actor derives a great deal of its effectiveness for the network-as-structure" (1998:207).

Following Keck and Sikkink, the current literature in international relations acknowledges the structural dimension of network but focuses on network-as-actors. This paper intended to offer a theoretical conceptualization of the interplay between intra- and inter-network interactions by importing and adapting the two-level game theory. The next logical step would be to test this theoretical model more systematically, beyond this single case study.

Relying on the methods of social network analysis could be a useful strategy to test this theoretical model (Kahler, 2009; Hafner-Burton, Kahler and Montgomery, 2009). Social network analysis is a methodological approach that offers quantitative tools to measure the strength of a network, based on the magnitude and the frequency of the links among nodes. For example, networks' leaders could be identified through one of the several measurements of centrality, such as the sum of the ties between a leader and every other actors or the length of the path between the leader and every other actors. Similarly, the heterogeneity of a network, affecting its win-set, could be inferred from a measurement of density, which is the proportion of ties in a network relative to the total number possible. The leader's autonomy vis-à-vis the network, another variable affecting the win-set, could be indicated by the leader's prominence, which is the degree of centrality of the actors to whom the leader is connected, or the leader's betweenness, which is the number of paths between two actors in the network that pass through the leader. Such a measurement of networks' structural dimensions, inspired by social network analysis, could usefully contribute to our understanding of the interplay between intra and inter network interaction ${ }^{3}$.

3 That being said, some of the variables affecting a network's win-set do not have a pure structural dimension and could hardly be assessed by the methodological tools of social network analysis. This is the case, for example, of the 
It is important to remember, however, that structural dimensions of networks are likely to explain the outcome only if there is a shared belief that the participation of all stakeholders is essential. This is a necessary condition to import in the global governance literature the two-level game theory, which, in its classical form, assumes that the ratification of an international agreement by states is necessary to establish a cooperation. If decision makers do not share this belief, classic indicators of capabilities used in the interest group literature, such as financial resources, number of members, or connection to decision makers, are more likely to explain the relative influence of a given non-state actor. In fact, these more classic indicators continue to play a significant role as NGOs, industries, and others non state actors do not have a formal veto power in most international regimes. But as the belief that multi-stakeholder governance is the most desirable procedure in world politics is spreading, the former interplay between domestic and international politics could increasingly be substituted by the interplay between intra- and inter-network.

leader's preferences and the network tolerance to status quo. This is one of the reasons why network mapping techniques alone could not be sufficient and must be completed by a qualitative analysis. 


\section{BIBLIOGRAPHY}

Ahuja, Gautam. (2000) Collaboration Networks, Structural Holes, and Innovation: A Longitudinal Study. Administrative Science Quarterly 45(3): 425-455.

Allison, Graham T. (1971) Essence of Decision: Explaining the Cuban Missile Crisis. Boston, MA: Little, Brown and Company.

Allison, Graham T., And Morton H. Halperin. (1972) Bureaucratic Politics: A Paradigm and Some Policy Implications. World Politics 24(Suppl.): 40-79.

Boekle, Henning, Volker Rittberger, and Wolfgang Wagner. (1999) Norms and Foreign Policy: Constructivist Foreign Policy Theory. Tübinger Arbeitspapiere zur Internationalen Politik und Friedensforschung / Tübingen Working Papers No. 34a.

Burris, Scott C., Peter Drahos, AND Clifford Shearing. (2005) Nodal Governance. Australian Journal of Legal Philosophy 30: 30-58.

Burt, Ronald S. (1992) “Chapter 1: The Social Structure of Competition.” In Structural Holes: The Social Structure of Competition, pp. 8-49. Cambridge, MA: Harvard University Press.

Carpenter, Charli R. (2007) Setting the Advocacy Agenda: Theorizing Issue Emergence and Nonemergence in Transnational Advocacy Networks. International Studies Quarterly 51(1): 99-120.

Cashore, Benjamin. (2002) Legitimacy and the Privatization of Environmental Governance: How Non State MarketDriven (NSMD) Governance Systems Gain Rule Making Authority. Governance: An International Journal of Policy and Administration 15(4): 503-529.

CUMmings, JONATHON. (2002) Managing the Innovation Process. MIT Open Courseware. <http://ocw.mit.edu/OcwWeb/Sloan-School-of-Management/15-351Managing-the-InnovationProcessFall2002/CourseHome/>.

DiAni, MARIO. (2002) "Network Analysis." In Methods of Social Movement Research, edited by Bert Klandermans and Suzanne Staggenborg, pp. 173-200. Minneapolis, MN: University of Minnesota Press.

Downs, ANTHONY. (1967) Inside Bureaucracy. Boston, MA: Little, Brown and Company.

Drahos, Peter. (2004) Securing the Future of Intellectual Property: Intellectual Property Owners and their Nodally Coordinated Enforcement Pyramid. Case Western Reserve Journal of International Law 36(1): 53-77.

Drahos, Peter, And John Braithwaite. (2003) Information Feudalism: Who Owns the Knowledge Economy? New York, NY: The New Press.

Evans, Peter B. (1993) "Building an Integrative Approach to International and Domestic Politics: Reflections and Projections.” In Double-Edged Diplomacy: International Bargaining and Domestic Politics, edited by P. B. Evans, H. K. Jacobson, and R. D. Putnam, pp. 397-430. Berkeley, CA: University of California Press.

Finnemore, Martha, AND KATHRYN SiKkINK. (1998) International Norm Dynamics and Political Change. International Organization 52(4): 887-917.

Friedman, Steven, And Shauna Mottiar. (2005) A Rewarding Engagement? The Treatment Action Campaign and the Politics of HIV/AIDS. Politics E⿱ Society 33(4): 511-565.

GanZ, Marshall. (2003) "Why David Sometimes Wins: Strategic Capacity in Social Movements." In Rethinking Social Movements: Structure, Meaning, and Emotion, edited by J. Goodwin and J. M. Jasper, pp. 177-198. Lanham, MD: Rowman \& Littlefield Publications.

Government of CANADA. December 14, 2007. Report on the Statutory Review of Sections 21.01 to 21.19 of the Patent Act. <http://camr-rcam.hc-sc.gc.ca/review-reviser/camr_rcam_report_rapport_e.html>.

Gusfield, JosePH R. (1966) Function Areas of Leadership in Social Movements. Sociological Quarterly 7(2): 137-156.

HaAs, Peter M. (2004) Addressing the Global Governance Deficit. Global Environmental Politics 4(4): 1-15.

Hafner-Burton, Emilie, Miles Kahler, AND AleXAnder H. MOnTGOMERy (2009) Network Analysis for

International Relations. International Organization, forthcoming 2009.

Halbert, Debora J. (2005) Resisting Intellectual Property. London, UK and New York, NY: Routledge.

HARGADON, ANDREW B. (1998) Firms as Knowledge Brokers: Lessons in Pursuing Continuous Innovation. California Management Review 40(3): 209-227.

Kahler, Miles (2009) "Network Politics: Agency, Power and Governance." In Networked Politics: Agency, Power and Governance, edited by M. Kahler, pp.1-22 Ithaca (NY): Cornell University Press.

KapoOR, ILAN. (2004) Deliberative Democracy and the WTO. Review of International Political Economy 11(3): $522-541$.

KarkKainen, Bradley C. (2004) Post-Sovereign Environmental Governance. Global Environmental Politics 4(1): 72-96.

Keck, Margaret E., AND Kathryn SikkinK. (1998) Activists Beyond Borders: Advocacy Networks in International Politics. London, UK and Ithaca, NY: Cornell University Press.

KNOKe, DAVID. (1990) Political Networks: The Structural Perspective. New York, NY: Cambridge University Press. 
KnOKe, DAVID, AND James H. KuKLinski. (1982) Network Analysis. Beverly Hills, CA: Sage Publications.

Krackhardt, David, AND JefFrey Hanson. (1993) Informal Networks: The Company Behind the Chart. Harvard Business Review 71(4): 104-111.

LI, Charlene. July 15, 2004. Profiles: The Real Value of Social Networks. (Forrester Research: Trend Report) <http://www.forrester.com/Research/Document/Excerpt/0,7211,34432,00.html>.

LIEBOWITZ, JAY. (2007) Social Networking: The Essence of Innovation. Lanham, MD: Scarecrow Press.

MALNES, RAINO. (1995) 'Leader' and 'Entrepreneur' in International Negotiations: A Conceptual Analysis. European Journal of International Relations 1(1): 87-112.

MARX, GARY T., AND MiChaEl UsEem. (1971) Majority Involvement in Minority Movements: Civil Rights, Abolition, Untouchability. Journal of Social Issues 27(1): 81-104.

Mayne, Ruth. (2002) "The Global Campaign on Patents and Access to Medicines: An Oxfam Perspective." In Global Intellectual Property Rights: Knowledge, Access, and Development, edited by P. Drahos and R. Mayne, pp. 244-258. New York, NY: Palgrave Macmillan.

MorAVCSIK, ANDREW. (1993) "Introduction: Integrating International and Domestic Theories of International Bargaining." In Double-Edged Diplomacy: International Bargaining and Domestic Politics, edited by P. B. Evans, H. K. Jacobson, and R. D. Putnam, pp. 3-42. Berkeley, CA: University of California Press.

Morris, Aldon D., AND SuzAnne Staggenborg. (2004) "Leadership in Social Movements." In The Blackwell Companion to Social Movements, edited by D. A. Snow, S. A. Soule, and H. Kriesi, pp. 171-196. Malden, MA: Blackwell Publishing.

MowJeE, TASNEEM. (2003) "Campaign to Increase Access to HIV/AIDS Drugs.” In Globalizing Civic Engagement: Civil Society and Transnational Action, edited by J. D. Clark, pp. 66-85. London, UK: Earthscan Publications.

Müller, Harald. (2004) Arguing, Bargaining and all that: Communicative Action, Rationalist Theory and the Logic of Appropriateness in International Relations. European Journal of International Relations 10(3): 395-435.

POWEll, Walter W., KenNeth W. Koput, and LAUREl SMith-DOERR. (1996) Interorganizational Collaboration and the Locus of Innovation: Networks of Learning in Biotechnology. Administrative Science Quarterly 41(1): 116-145.

Pugatch, Meir Perez. (2007) "Political Economy of Intellectual Property Policy-Making: Theory and Practice - An Observation from a Realistic (and Slightly Cynical) Perspective.” In New Directions in Copyright Law (volume 5), pp. 95-118. Cheltenham,UK and Northampton, MA: Fiona Macmillan.

Putnam, Robert D. (1988) Diplomacy and Domestic Politics: The Logic of Two-Level Games. International Organization 42(3): 427-460.

ReImanN, Kim D. (2006) A View from the Top: International Politics, Norms and the Worldwide Growth of NGOs. International Studies Quarterly 50(1): 45-68.

Risse, Thomas. (2000) "Let's Argue!”: Communicative Action in World Politics. International Organization 54(1): 1-39.

Rogers, Everett M. (1995) “Chapter 1: Elements of Diffusion.” In Diffusion of Innovations, $4^{\text {th }}$ edition, pp. 1-37. New York, NY: The Free Press.

Rosenau, JAmEs N. (1992) “Citizenship in a Changing Global Order.” In Governance Without Government: Order and Change in World Politics, edited by J. N. Rosenau and E.-O. Czempiel, pp. 272-294. New York, NY: Cambridge University Press.

Rosenau, James N. (1992) "Governance, Order, and Change in World Politics." In Governance Without Government: Order and Change in World Politics, edited by J. N. Rosenau and E.-O. Czempiel, pp. 1-29. New York, NY: Cambridge University Press.

Rucht, Dieter. (2002) "Movement Allies, Adversaries, and Third Parties." In The Blackwell Companion to Social Movements, edited by D. A. Snow, S. A. Soule, and H. Kriesi, pp. 197-216. Malden, MA: Blackwell Publishing.

ScotT, John. (1992) Social Network Analysis: A Handbook. London, UK: Sage Publications.

SELL, SUSAN K. (2002) TRIPS and the Access to Medicines Campaign. Wisconsin International Law Journal 20(3): 481522.

Sell, Susan K. (2003) Private Power, Public Law: The Globalization of Intellectual Property Rights. Cambridge, UK: Cambridge University Press.

Sell, Susan K., AND Aseem Prakash. (2004) Using Ideas Strategically: The Contest between Business and NGO Networks in Intellectual Property Rights. International Studies Quarterly 48(1): 143-175.

Sending, Ole Jacob, AND Iver B. NeumanN. (2006) Governance to Governmentality: Analysing NGOs, States, and Power. International Studies Quarterly 50(3): 651-672.

Shadlen, Kenneth C. (2007) The Political Economy of AIDS Treatment: Intellectual Property and the Transformation of Generic Supply. International Studies Quarterly 51(3): 559-581.

Slaughter, Anne-Marie, Andrew S. Tulumello, And Stepan Wood. (1998) "International Law and International Relations Theory: A New Generation of Interdisciplinary Scholarship. The American Journal of International Law 92(3): 367-397. 
Steinberg, Richard H. (2002) In the Shadow of Law or Power? Consensus-Based Bargaining and Outcomes in the GATT/WTO. International Organization 56(2): 339-374.

Stuart, ToBy E. (1998) Network Positions and Propensities to Collaborate: An Investigation of Strategic Alliance Formation in a High-Technology Industry. Administrative Science Quarterly 43(3): 668-698.

Tarrow, Sidney. (1989) Struggle, Politics, and Reform: Collective Action, Social Movements, and Cycles of Protest. (Western Societies Program Occasional Paper No 21.) Ithaca, NY: Cornell University Center for International Studies.

'T Hoen, Ellen F. M. (2002) TRIPS, Pharmaceutical Patents and Access to Essential Medicines: A Long Way From Seattle to Doha. Chicago Journal of International Law 3: 27-46.

ThÉRien, JeAn-PhilipPe, AND Vincent Pouliot. (2006) The Global Compact: Shifting the Politics of Development? Global Governance 12(1): 55-75.

ThOmson, Janice E. (1992) "Explaining the Regulation of Transnational Practices: A State-Building Approach.” In Governance Without Government: Order and Change in World Politics, edited by J. N. Rosenau and E.-O. Czempiel, pp. 195-218. New York, NY: Cambridge University Press.

Wolpert, JOHN D. (2002) Breaking out of the Innovation Box. Harvard Business Review 80(2): 77-83.

YOUNG, ORAN R. (1992) “The Effectiveness of International Institutions: Hard Cases and Critical Variables." In Governance Without Government: Order and Change in World Politics, edited by J. N. Rosenau and E.-O. Czempiel, pp. 160-194. New York, NY: Cambridge University Press.

ZACHER, MARK W. (1992) “The Decaying Pillars of the Westphalian Temple: Implications for International Order and Governance." In Governance Without Government: Order and Change in World Politics, edited by J. N. Rosenau and E.O. Czempiel, pp. 58-101. New York, NY: Cambridge University Press. 
ANNEX 1: LIST OF INTERVIEWEES

\begin{tabular}{|c|c|c|}
\hline INTERVIEWEE & AFFILIATION & DATE OF INTERVIEW \\
\hline ABBOTt, FREDERICK M. & Florida State University & January 16, 2007 \\
\hline ADDOR, FELIX & Swiss Federal Institute of Intellectual Property & February 14, 2007 \\
\hline ARMSTRONG, CHRISTOPHER & Canadian International Development Agency & January 17, 2007 \\
\hline AUSTIN, SARA & World Vision & August 23, 2006 \\
\hline BENNETT, CATHERINE & Formerly with Pfizer & October 6, 2006 \\
\hline BERGER, JONATHAN & AIDS Law Project (South Africa) & April 2, 2007 \\
\hline BLOUIN, CHANTAL & North South Institute & June 21, 2006 \\
\hline BONIN, MARIE-HÉLÈNE & Formerly with Médecins Sans Frontières & November 8, 2006 \\
\hline CHARLES, FURAYA & Government of Rwanda & November 20, 2007 \\
\hline CLARK, BRUCE AND HEMS, JOHN & Apotex & January 30, 2007 \\
\hline ClaRK, DOUGLASS & Industry Canada & November17, 2006 \\
\hline CONNELL, JEFF & Canadian Generic Pharmaceutical Association & January 30, 2007 \\
\hline DRUMMOND, JOHN & Department of Foreign Affairs (Canada) & October 31, 2006 \\
\hline ELLIOTT, RICHARD & Canadian HIV/AIDS Legal Network & January 31, 2007 \\
\hline ELOUARDIGHI, KHALIL & Act Up Paris & October 30, 2006 \\
\hline FINSTON, SUSAN & Formerly with PhRMA & October 5, 2006 \\
\hline FOSTER, JOHN & North South Institute & September 8, 2006 \\
\hline FRIED, MARK & Oxfam & September 8, 2006 \\
\hline GEORGE, DOUGLAS AND BOISVERT, JULIE & International Trade Canada & September 7, 2006 \\
\hline GERHARDSEN, TOVE IREN & IP Watch & November 1, 2006 \\
\hline GORLIN, JACQUES & Gorlin Group & October 5, 2006 \\
\hline JENNINGS, MARLENE & Member of the Canadian Parliament & October 10, 2006 \\
\hline JORGE, FABIANA AND CULLEN, DOLORES & MFJ International & October 6, 2006 \\
\hline KIDDELL-MONROE, RACHEL & Médecins Sans Frontières & November 10, 2006 \\
\hline KURJI, FEYROUZ & Formerly at the Private Council Office (Canada) & January 10, 2007 \\
\hline LEE, DAVID K. & Health Canada & September 8, 2006 \\
\hline LEWIS-LETTINGTON, ROBERT & Genetic Resources Policy Initiative (Kenya) & April 4, 2007 \\
\hline LEXCHIN, JOEL & York University & January 31, 2007 \\
\hline LOVE, JAMES & Knowledge Ecology International & September 23, 2006 \\
\hline MATTHEWS, MERRILL & Institute for Policy Innovation & November 2, 2006 \\
\hline MCCOOL, TERRY & Eli Lilly & February 8, 2007 \\
\hline MCCOY, STANFORD & United State Trade Representative Office & October 6, 2006 \\
\hline Musungu, Sisule & South Center & November 10, 2006 \\
\hline NOEHRENBERG, ERIC & $\begin{array}{l}\text { International Federation of Pharmaceutical } \\
\text { Manufacturers and Associations }\end{array}$ & November 1, 2006 \\
\hline
\end{tabular}


O'CONNOR, MICHAEL

OTTEN, AdRIAN AND WATAL, JaYASHREE

Passarelli, CARlos

PATRY, BERNARD

Pettigrew, Pierre

Pitts, Peter

Pugatch, MEIR

SMITH, ERIC

SMITH, PATRICK

SPENNEMANN, CHRISTOPH

SREENIVASAN, GAURI

TAMAKLOE, JOSEPH

TAUBMAN, ANTONY

Twiss, CAROLINE

VANDOREN, PAUl AND RAVILlaRd, PATRICK

VAN-EeckHaute, Jean ChaRles

VELASQUEZ, GERMAN

WEISSMAN, ROBERT

WILLIAMS, RUSSELL

YONG-D’HERVÉ, DAPHNÉ
Interagency Coalition on AIDS and Development

World Trade Organization

Government of Brazil

Member of the Canadian Parliament

Former Canadian Minister of International Trade

Center for Medicines in the Public Interest

The Stockholm Network

International Intellectual Property Alliance

Intellectual Property Institute of Canada

UNCTAD

Canadian Council for International Cooperation

Ghanaian Patent Office

WIPO

Canadian Activist

European Commission

European Commission

World Health Organization

Essential Action

Canada's Research-Based Pharmaceutical Companies

International Chamber of Commerce
November 8, 2006

October 31, 2006

December 13, 2007

November 8, 2006

December 14, 2006

January 25, 2007

December 20, 2006

October 6, 2006

January 22, 2007

November 1, 2006

September 7, 2006

November 16, 2007

January 17, 2007

March 7, 2007

December 13, 2006

December 19, 2006

October 31, 2006

October 5, 2006

December 20, 2006

December 5, 2006 